\title{
OPTIMIZATION OF FORMABILITY OF TAILOR-WELDED BLANKS
}

\author{
OPTIMIZACIJA OBLIKOVANJA PRILAGOJENIH VARJENIH \\ SUROVCEV
}

\author{
Valarmathi Guruvu${ }^{1}$, Ramanathan Kalimuthu' ${ }^{1}$, Sathiya Narayanan Chinnaiyan ${ }^{2}$, \\ Kathiresan Marimuthu ${ }^{3}$ \\ 1Alagappa Chettiar College of Engineering \& Technology, Department of Mechanical Engineering, Karaikudi - 630004, Tamilnadu, India \\ ${ }^{2}$ National Institute of Technology, Department of Production Engineering, Tiruchirappalli - 620015, Tamilnadu, India \\ ${ }^{3}$ Thiagarajar College of Engineering, Department of Mechanical Engineering, Madurai - 625015, Tamilnadu, India \\ umkathir@gmail.com \\ Prejem rokopisa - received: 2017-05-18; sprejem za objavo - accepted for publication: 2017-07-28
}

doi: $10.17222 /$ mit.2017.058

Nowadays tailor-welded blanks (TWBs) are used in the automotive industries to meet economic concerns, government regulations and design of vehicles with reduced weight and allow cost reduction. This technique is also employed while improving structural integrity and crash performance. Due to the raising environmental concerns about automotive emissions and the scarcity of natural resources, we need to reduce vehicle weight and improve fuel economy. As a result, the automotive industries employ TWBs. In this work, three grades of aluminum sheets $(5052,6061$ and 8011$)$ with a 2 -mm thickness were made thinner by cold rolling, obtaining three different thicknesses of $(0.8,1.0$ and 1.2$) \mathrm{mm}$. Sheets were then joined using the cold-metal-transfer (CMT) welding process. The Taguchi design of experiment (DOE) was carried out for the $L_{27}$ orthogonal array with nine variables at three levels. Due to this optimization process, the welding decreased the formability of TWBs compared with the parent material and this was reflected in the forming behavior, represented by the strain-distribution profiles. Keywords: tailor-welded blanks, aluminum alloy, incremental forming, cold metal transfer

Dandanes se zaradi ekonomičnosti, vladnih regulativ, dizajna vozil z zmanjšanjo težo in zaradi zmanjševanja stroškov v avtomobilski industriji uporabljajo prilagojeni varjeni surovci (angl. TWBs). Ta tehnika se uporablja tudi zaradi izboljšanja strukturne celovitosti in obnašanja pri nesrečah. Zaradi povečanja okoljskih vprašanj glede emisij izpušnih plinov in pomanjkanja naravnih virov, je treba zmanjšati težo vozila in izboljšati ekonomičnost porabe goriva. Posledično avtomobilska industrija uporablja prilagojene varjene surovce (TWB). V prispevku so bili trije sloji pločevine aluminija $(5052,6061$ in 8011$)$, $\mathrm{z}$ debelino $2 \mathrm{~mm}$, stanjšani s postopkom hladnega valjanja na tri različne debeline $(0,8,1,0$ in 1,2$)$ mm. Plasti aluminija so bile nato združene s postopkom varjenja s kovinskim prenosom (angl. CMT). Taguchijeva metoda načrtovanja eksperimentiranja (angl. DOE) je bila opravljena za $L_{27}$ ortogonalno polje z devetimi spremenljivkami na treh ravneh. Iz tega optimizacijskega procesa varjenje zmanjša sposobnost TWB v primerjavi z originalnim materialom, kar se odraža v obnašanju formiranj, ki ga predstavljajo profili razdeljevanja sevov.

Ključne besede: prilagojeni varjeni surovci, aluminijeva zlitina, postopno oblikovanje, hladen transfer kovine

\section{INTRODUCTION}

Aluminum and its alloys exhibit many attractive characteristics including light weight, high specific strength, high thermal and electrical conductivity. Aluminum also exhibits poor weldability due to its high reflectivity, low molten viscosity and the existence of oxide layers. Therefore, much research work on aluminum tailor-welded blanks with different thicknesses and various alloy combinations is in progress. Tailored blanks are the collective for semi-finished sheet products, characterized by the local sheet thickness, sheet material, coating or material properties. TWBs ensure that the components are light, stronger and provide the required functionality at a low cost. Incremental sheetmetal forming (ISMF) is a process, in which a sheet is formed incrementally through a progression of localized deformation. For small, batch-size products, there is no need for specialized dies in ISMF. Cold metal transfer (CMT) is an automated dip-transfer welding, charac- terized by controlled material deposition to the workpiece during the short circuit of the wire electrode.

Single-point incremental forming (SPIF) is a flexible sheet-metal-forming method adapted to form various complex shapes using a CNC milling machine, a multiaxis robot or a dedicated machine without the use of specific and costly tools, such as a punch and die. ${ }^{1}$ SPIF can be used to form small or large pieces, based upon the machine size for the various components. Furthermore, the SPIF process, which is based on the forming limit diagram (FLD) used to achieve a higher formability compared to the conventional forming process, can be adapted to the materials such as the Al-Mg-Si alloy. ${ }^{2}$ SPIF is used to form TWBs and also to improve the forming limit. However, the shape inaccuracy, which is usually an important limiting factor for SPIF applications is to be solved. Several mechanisms used for the enhanced formability of the SPIF process were already presented. ${ }^{3}$ A further elaborate study on the incremental sheet forming regarding individual sheet quality is 
required. The mechanical properties of friction-stirwelded dissimilar aluminum alloys AA5052 and AA6061 using a cylindrical-pin tool are analyzed. ${ }^{4}$ The cold metal transfer (CMT) is an innovative process based on short-circuiting metal transfer, introducing a relatively low heat into the weld seam and this reduces the formation of intermetallics and thermal distortion. ${ }^{5}$ The welding of such hybrid joints is a big challenge due to large differences in the melting point and thermal expansion of aluminum alloys. The formation of excessive intermetallic compounds (IMCs) at elevated temperatures also reduces the joint strength. ${ }^{6}$

Cold metal transfer requires no spatter welding; it uses a low heat input during the welding and provides for a good performance of joining dissimilar metals, like aluminum and zinc-coated steel. ${ }^{7}$ When joining three types of aluminum alloy with mild steel, design of experiments technique (DOE) is used to optimize the welding parameters. The effect of the intermetallic-layer thickness was also analyzed. ${ }^{8}$ An advanced CMT method and optimized welding parameters were used to join dissimilar metals. The effect of the filler material on the wettability of the base material was also studied..$^{9}$ In this
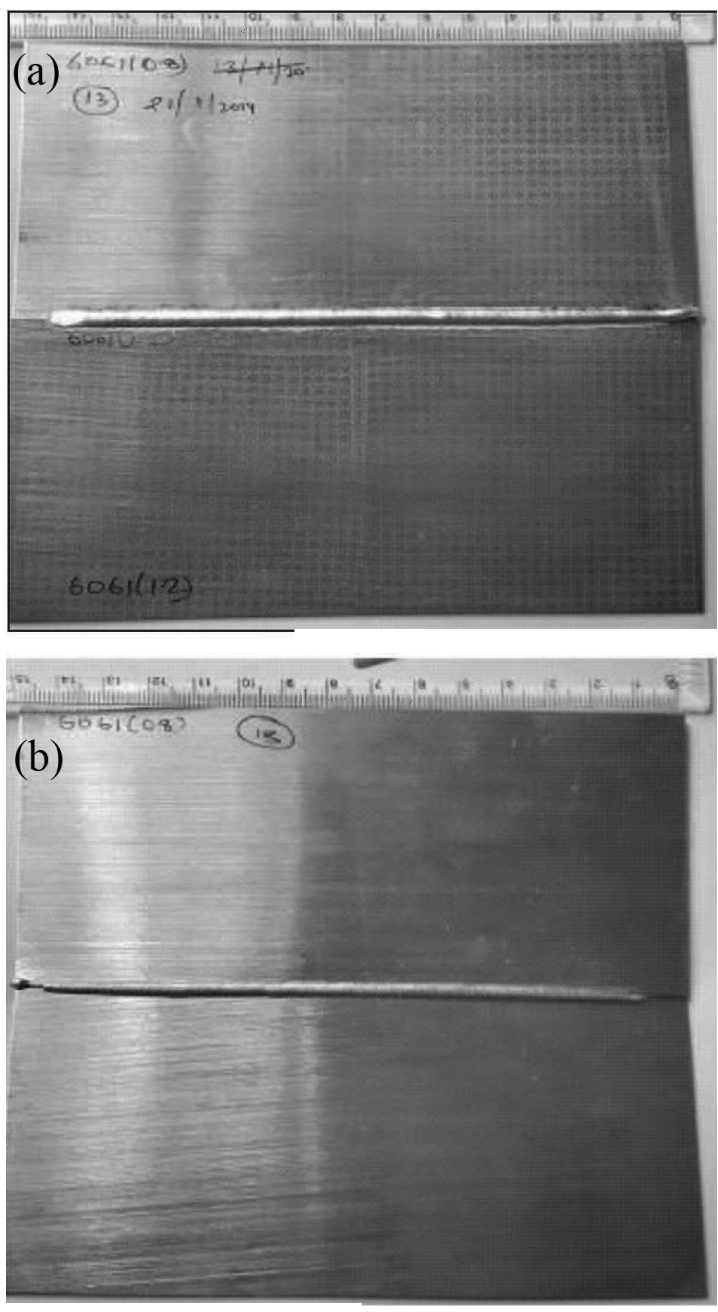

Figure 1: Specimens of TWBs: a) top surface, b) bottom surface
Table 1: Variables and levels of $L_{27}$ DOE

\begin{tabular}{|c|l|c|c|c|}
\hline No. & \multicolumn{1}{|c|}{ Variable } & Level 1 & Level 2 & Level 3 \\
\hline 1 & $1^{\text {st }}$ material & 5052 & 6061 & 8011 \\
\hline 2 & Thickness of $1^{\text {st }}$ material & $0.8 \mathrm{~mm}$ & $1.0 \mathrm{~mm}$ & $1.2 \mathrm{~mm}$ \\
\hline 3 & $2^{\text {nd }}$ material & 5052 & 6061 & 8011 \\
\hline 4 & Thickness of $2^{\text {nd }}$ material & $0.8 \mathrm{~mm}$ & $1.0 \mathrm{~mm}$ & $1.2 \mathrm{~mm}$ \\
\hline 5 & Spindle speed & $300 \mathrm{~min}^{-1}$ & $450 \mathrm{~min}^{-1}$ & $600 \mathrm{~min}^{-1}$ \\
\hline 6 & Feed & $\begin{array}{c}300 \\
\mathrm{~mm} / \mathrm{min}\end{array}$ & $\begin{array}{c}600 \\
\mathrm{~mm} / \mathrm{min}\end{array}$ & $\begin{array}{c}900 \\
\mathrm{~mm} / \mathrm{min}\end{array}$ \\
\hline 7 & VSD & $0.2 \mathrm{~mm}$ & $0.4 \mathrm{~mm}$ & $0.6 \mathrm{~mm}$ \\
\hline 8 & Weld speed & $\begin{array}{c}400 \\
\mathrm{~mm} / \mathrm{min}\end{array}$ & $\begin{array}{c}500 \\
\mathrm{~mm} / \mathrm{min}\end{array}$ & $\begin{array}{c}600 \\
\mathrm{~mm} / \mathrm{min}\end{array}$ \\
\hline 9 & Lubricant & dry & $\begin{array}{c}\text { coconut } \\
\text { oil }\end{array}$ & grease \\
\hline
\end{tabular}

Table 2: $L_{27}$ DOE (design of experiment) table using Taguchi method

\begin{tabular}{|c|c|c|c|c|c|c|c|c|c|}
\hline \multirow[b]{2}{*}{ No. } & \multicolumn{2}{|c|}{$1^{\text {st }}$ material } & \multicolumn{2}{|c|}{$2^{\text {nd }}$ material } & \multirow[b]{2}{*}{ 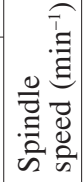 } & \multirow[b]{2}{*}{ } & \multirow[b]{2}{*}{$\begin{array}{l}\hat{\approx} \\
> \\
>\end{array}$} & \multirow[b]{2}{*}{ 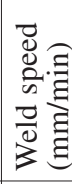 } & \multirow[b]{2}{*}{ 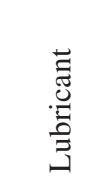 } \\
\hline & $\begin{array}{l}\stackrel{\tilde{\omega}}{0} \\
\tilde{D} \\
\tilde{n}\end{array}$ & 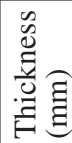 & $\begin{array}{l}\tilde{0} \\
\stackrel{0}{0} \\
\tilde{n}\end{array}$ & 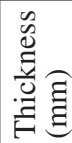 & & & & & \\
\hline 1 & 5052 & 0.8 & 5052 & 0.8 & 300 & 300 & 0.2 & 400 & dry \\
\hline 2 & 5052 & 0.8 & 5052 & 0.8 & 450 & 600 & 0.4 & 500 & coconut \\
\hline 3 & 5052 & 0.8 & 5052 & 0.8 & 600 & 900 & 0.6 & 600 & grease \\
\hline 4 & 5052 & 1.0 & 6061 & 1.0 & 300 & 300 & 0.2 & 500 & coconut \\
\hline 5 & 5052 & 1.0 & 6061 & 1.0 & 450 & 600 & 0.4 & 600 & grease \\
\hline 6 & 5052 & 1.0 & 6061 & 1.0 & 600 & 900 & 0.6 & 400 & dry \\
\hline 7 & 5052 & 1.2 & 8011 & 1.2 & 300 & 300 & 0.2 & 600 & grease \\
\hline 8 & 5052 & 1.2 & 8011 & 1.2 & 450 & 600 & 0.4 & 400 & dry \\
\hline 9 & 5052 & 1.2 & 8011 & 1.2 & 600 & 900 & 0.6 & 500 & coconut \\
\hline 10 & 6061 & 0.8 & 6061 & 1.2 & 300 & 600 & 0.6 & 400 & coconut \\
\hline 11 & 6061 & 0.8 & 6061 & 1.2 & 450 & 900 & 0.2 & 500 & grease \\
\hline 12 & 6061 & 0.8 & 6061 & 1.2 & 600 & 300 & 0.4 & 600 & dry \\
\hline 13 & 6061 & 1.0 & 8011 & 0.8 & 300 & 600 & 0.6 & 500 & grease \\
\hline 14 & 6061 & 1.0 & 8011 & 0.8 & 450 & 900 & 0.2 & 600 & dry \\
\hline 15 & 6061 & 1.0 & 8011 & 0.8 & 600 & 300 & 0.4 & 400 & coconut \\
\hline 16 & 6061 & 1.2 & 5052 & 1.0 & 300 & 600 & 0.6 & 600 & dry \\
\hline 17 & 6061 & 1.2 & 5052 & 1.0 & 450 & 900 & 0.2 & 400 & coconut \\
\hline 18 & 6061 & 1.2 & 5052 & 1.0 & 600 & 300 & 0.4 & 500 & grease \\
\hline 19 & 8011 & 0.8 & 8011 & 1.0 & 300 & 900 & 0.4 & 400 & grease \\
\hline 20 & 8011 & 0.8 & 8011 & 1.0 & 450 & 300 & 0.6 & 500 & dry \\
\hline 21 & 8011 & 0.8 & 8011 & 1.0 & 600 & 600 & 0.2 & 600 & coconut \\
\hline 22 & 8011 & 1.0 & 5052 & 1.2 & 300 & 900 & 0.4 & 500 & dry \\
\hline 23 & 8011 & 1.0 & 5052 & 1.2 & 450 & 300 & 0.6 & 600 & coconut \\
\hline 24 & 8011 & 1.0 & 5052 & 1.2 & 600 & 600 & 0.2 & 400 & grease \\
\hline 25 & 8011 & 1.2 & 6061 & 0.8 & 300 & 900 & 0.4 & 600 & coconut \\
\hline 26 & 8011 & 1.2 & 6061 & 0.8 & 450 & 300 & 0.6 & 400 & grease \\
\hline 27 & 8011 & 1.2 & 6061 & 0.8 & 600 & 600 & 0.2 & 500 & dry \\
\hline
\end{tabular}

work, the single-point incremental forming of TWBs consisting of aluminum-alloy sheets made with coldmetal-transfer welding was studied and optimization of the process parameters was carried out using the Taguchi method.

\section{EXPERIMENTAL PART}

Three grades of aluminum (5052, 6061 and 8011) with a $2-\mathrm{mm}$ thickness were made into sheets with three different thicknesses of $(0.8,1.0$ and 1.2) $\mathrm{mm}$, using 


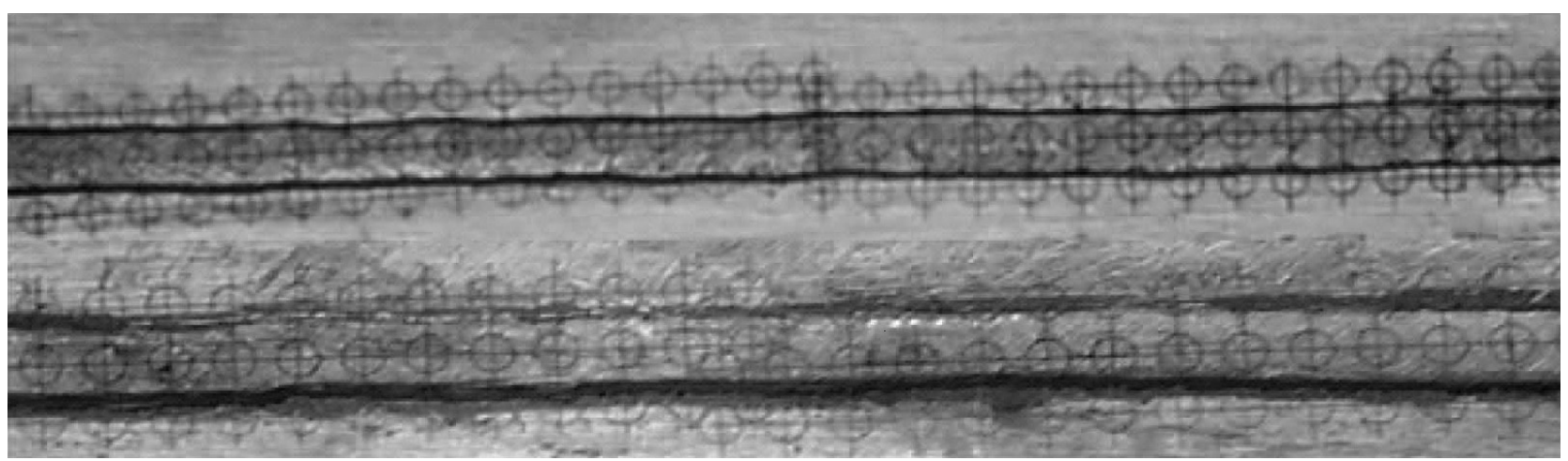

Figure 2: Grid marking on welds: TWB No. 1 (AA6061 (1.2 mm) + AA5052 (1.2 mm))

cold-rolling processes. The sheets were welded using cold-metal-transfer welding. Using the Taguchi method, the $L_{27}$ orthogonal array with 9 variables in 3 levels were used for the design of experiments as shown in Table $\mathbf{1 .}$ The data regarding the $L_{27}$ design of experiments are shown in Table 2. TWB specimens are shown in Figure 1. In this work, a $200 \mathrm{~W}$ Nd-YAG laser is used for grid marking. The diameters of grid circles are $2 \mathrm{~mm}$, the width of grid lines are $1 \mu \mathrm{m}$ and the grid marking is shown in Figure 2.

\subsection{Selection of the incremental-forming tool}

A hemispherical-end tool with a $10-\mathrm{mm}$ diameter and $100-\mathrm{mm}$ length was used for incremental sheet-metal forming. With this tool, we can form the sheet metal, which is rigidly fixed onto a blank holder. The sheet forming is carried out by passing the feed incrementally to the tool.

\subsection{Incremental sheet metal and straight groove}

Single-point-incremental-forming tests were carried out using a 3-axis CNC machine as shown in Figure 3. In all the tests, a punch with a hemispherical head was used and grease/coconut oil was applied as the lubricant

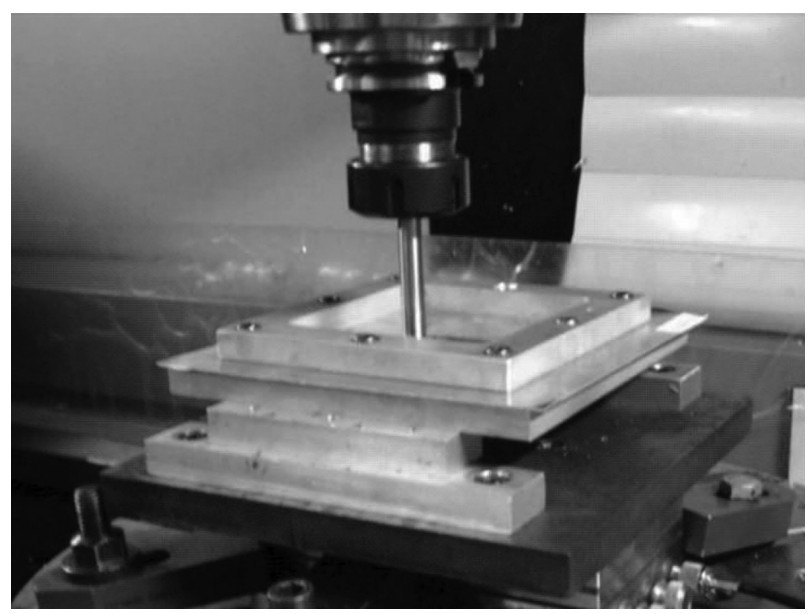

Figure 3: Experimental set-up to reduce friction. An experimental blank of $150 \mathrm{~mm} \times$ $150 \mathrm{~mm}$ was clamped to a properly designed framework. Circular grids of a 2-mm diameter were marked on the surfaces of aluminum sheets using a laser beam of $200 \mathrm{~W}$, while the width of a grid line was $1 \mu \mathrm{m}$. The punch movement was determined with pure-stretchingdeformation mechanics. Throughout the process, the punch head had a 10-mm diameter, and it determined the expansion of the blank, which underwent plastic deformation due to the punch movement, while its tool path was controlled using the part program. For each test, the tool trajectory depended on the testing conditions. Such trajectories included both the horizontal and vertical movements of the tool. The present work was focused on investigating the material formability. The test continuously varied with the wall angle and the wall angle of breakage depended upon the material, the thickness of the sheet and the grain orientation. Due to the localized action of the small hemispherical punch, the blank underwent a local thinning. Then the closest zone of the blank was deformed without a significant effect on the already deformed one. Therefore, forming limits must be identified, for any material, in terms of the critical threshold of the allowable local thinning. According to the above considerations, the strain path in incremental forming is typically very close to the major axis in the diagram and fracture strains are remarkably larger than the conventional stamping. Much higher strains can be achieved with incremental forming than with the traditional processes. During the straight-groove test, grooves were made in the direction of rolling. The size of grids is measured using a digital USB microscope.

\section{RESULTS AND DISCUSSIONS}

The experiments from 1 to 27 were carried out as per the DOE table, as shown in Table 2. The welding image of the first experiment condition is shown in Figure 4. The formability achieved along the transverse of the weld was 0.955 . A failure occurred on the weld because it exceeded the forming limit. The formability achieved along the weld was 0.32 and a failure occurred due to a 

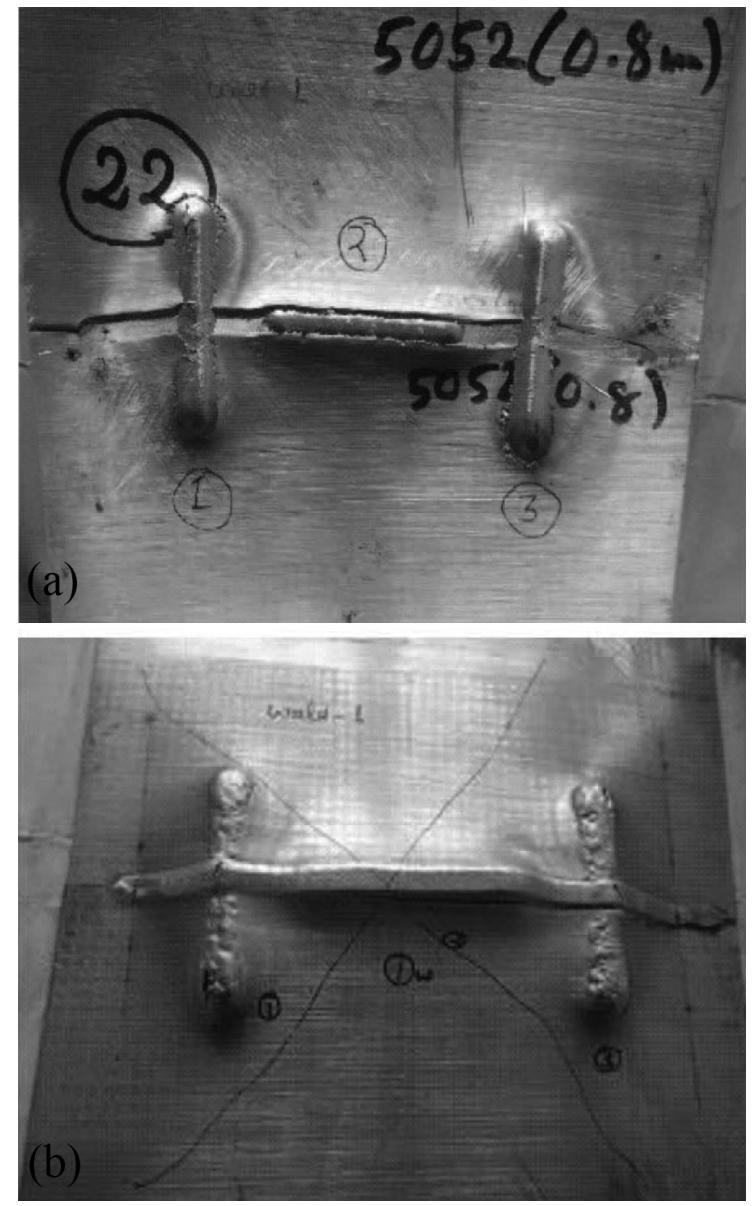

Figure 4: Images of formed TWB No. 1: a) top surface, b) bottom surface

poor weld quality. A tearing failure occurred along the weld direction. In the conventional forming, the ' $n$ ' value for AA5052 $(0.8 \mathrm{~mm})$ is 0.1354 , which is lower than the achieved formability for TWB No. 1. Similarly, the same process was repeated for all the conditions listed in Table 2 and from the forming limit diagram, the formability values achieved along 'the transverse of the weld direction' and 'along the weld direction' are shown in Table 3.
Table 3: Formability achieved during forming

\begin{tabular}{|c|c|c|c|c|c|}
\hline Ex. No. & $\begin{array}{c}\text { Trans- } \\
\text { verse of } \\
\text { the weld }\end{array}$ & $\begin{array}{c}\text { Along the } \\
\text { weld }\end{array}$ & Ex. No. & $\begin{array}{c}\text { Trans- } \\
\text { verse of } \\
\text { the weld }\end{array}$ & $\begin{array}{c}\text { Along the } \\
\text { weld }\end{array}$ \\
\hline 1 & 0.995 & 0.32 & 15 & 0.768 & 0.253 \\
\hline 2 & 0.522 & 0.395 & 16 & 0.6 & 0.232 \\
\hline 3 & 0.59 & 0.215 & 17 & 0.432 & 0.329 \\
\hline 4 & 0.477 & 0.176 & 18 & 0.573 & 0.307 \\
\hline 5 & 0.511 & 0.322 & 19 & 0.651 & 0.194 \\
\hline 6 & 0.381 & 0.239 & 20 & 0.698 & 0.44 \\
\hline 7 & 0.763 & 0.214 & 21 & 0.918 & 0.602 \\
\hline 8 & 0.524 & 0.348 & 22 & 0.658 & 0.214 \\
\hline 9 & 0.373 & 0.141 & 23 & 0.793 & 0.376 \\
\hline 10 & 0.311 & 0.076 & 24 & 0.599 & 0.294 \\
\hline 11 & 0.806 & 0.343 & 25 & 0.675 & 0.138 \\
\hline 12 & 0.693 & 0.18 & 26 & 1.2 & 0.963 \\
\hline 13 & 0.736 & 0.273 & 27 & 0.52 & 0.343 \\
\hline 14 & 0.668 & 0.321 & & & \\
\hline
\end{tabular}

\subsection{Taguchi analysis: forming along the transverse of the weld direction versus variables}

A response table for signal-to-noise ratios for the largest is better is shown in Table 4. The formability along the weldment and perpendicular to the weldment should be maximum until a rupture takes place. Hence, the larger the better condition is used. The formability parameters $-1^{\text {st }}$ material thickness of $1.2 \mathrm{~mm}, 2^{\text {nd }}$ material thickness of $0.8 \mathrm{~mm}$, the spindle speed of $450 \mathrm{~min}^{-1}$, the feed of $300 \mathrm{~mm} / \mathrm{min}$, VSD of $0.6 \mathrm{~mm}$, the weld speed of $400 \mathrm{~mm} / \mathrm{min}$ - are represented in the output graph based on the Taguchi analysis, which is same as that of the experiment.

\section{CONCLUSIONS}

Based on the results and discussion, the following conclusions are drawn:

- The $S / N$ ratio for both directions is maximum for experiment No. 26.

- This indicates that the incremental-forming behavior during experiment No. 26 in optimum and its para-

Table 4: $S / N$ ratio: largest is better

\begin{tabular}{|c|c|c|c|c|c|c|c|}
\hline 1st spindle & & & 2nd spindle & & & & \\
\hline Level & 1st series & thickness & 2nd series & thickness & speed & feed & VSD \\
\hline 1 & -5.272 & -3.675 & -4.104 & -2.916 & -4.094 & -2.521 & -3.596 \\
\hline 2 & -4.470 & -4.356 & -4.817 & -4.978 & -3.701 & -5.023 & -4.243 \\
\hline 3 & -2.801 & -4.511 & -3.620 & -4.648 & -4.747 & -4.997 & -4.703 \\
\hline Delta & 2.471 & 0.837 & 1.197 & 2.062 & 1.045 & 2.502 & 1.107 \\
\hline Rank & 2 & 9 & 6 & 3 & 8 & 1 & 7 \\
\hline Level & weld speed & lubricant & & & & & \\
\hline 1 & -4.485 & -4.178 & & & & & \\
\hline 2 & -4.717 & -5.171 & & & & & \\
\hline 3 & -3.340 & -3.193 & & & & & \\
\hline Delta & 1.377 & 1.979 & & & & & \\
\hline Rank & 5 & 4 & & & & & \\
\hline
\end{tabular}


meters are optimum for the formation of tailorwelded blanks.

- During the groove formation in the transverse direction, a failure occurs on the weld because it exceeds the forming limit and tearing occurs along the weld.

- Welding decreases the formability of the TWBs compared with the parent material, which is reflected in the forming behavior, represented by straindistribution profiles. This is due to the non-uniform strain distributions.

- The $S / N$ ratios for the largest is better are proved by the statistics and the Taguchi analysis, which is same as that of the experiment.

\section{REFERENCES}

${ }^{1}$ K. H. Wisam, J. H. Sarraji, W.-X. Ren, Experimental Investigations on Forming Time in Negative Incremental Sheet Metal Forming Process, Materials and Manufacturing Processes, 27 (2012) 5, 499-506, doi:10.1080/10426914. 2011. 585550

${ }^{2}$ H. Khalatbari, A. Iqbal, X. Shi, L. Gao, G. Hussain, M. Hashemipour, High-Speed Incremental Forming Process: A Trade-Off Between Formability and Time Efficiency, Materials and Manufacturing Processes, 30 (2015) 11, 1354-1363, doi:10.1080/ 10426914.2015.1037892

${ }^{3}$ W. C. Emmens, A. H. Van Den Boogaard, An overview of stabilizing deformation mechanisms in incremental sheet forming, Journal of Materials Processing Technology, 209 (2009) 8, 3688-3695, https://doi.org/10.1016/j.jmatprotec.2008.10.003
${ }^{4}$ V. R. Kumar, M. V. Kannan, P. Sadeesh, N. Arivazhagan, K. D. Ramkumar, Studies on effect of tool design and welding parameters on the friction stir welding of dissimilar aluminum alloys AA $5052-$ AA 6061, Procedia Engineering, 75 (2014), 93-97, doi:10.1016/ j.proeng.2013.11.019

${ }^{5}$ H. T. Zhang, J. C. Feng, P. He, Interfacial phenomena of cold metal transfer (CMT) welding of zinc coated steel and wrought aluminum, Materials Science and Technology, 24 (2008) 11, 1346, doi:10.1179/174328407X213152

${ }^{6}$ H. Dong, L. Yang, C. Dong, S. Kou, Arc joining of aluminum alloy to stainless steel with flux-cored $\mathrm{Zn}$-based filler metal, Materials Science and Engineering A, 527 (2010), 7151-7154, doi:10.1016/ j.msea.2010.07.092

${ }^{7}$ H. T. Zhang, J. C. Feng, P. He, B. B. Zhang, J. M. Chen, L. Wang, The arc characteristics and metal transfer behavior of cold metal transfer and its use in joining aluminum to zinc-coated steel, Materials Science and Engineering A, 499 (2009), 111-113, doi:10.1016/j.msea. 2007.11.124

${ }^{8}$ R. Cao, G. Yu, J. H. Chen, P.-C. Wang, Cold metal transfer joining aluminum alloys to galvanized mild steel, Journal of Materials Processing Technology, 213 (2013) 10, 1753-1763, doi:10.1016/ j.jmatprotec.2013.04.004

${ }^{9}$ S. Niu, S. Chen, H. Dong, D. Zhao, X. Zhang, X. Guo, G. Wang, Microstructure and Properties of Lap Joint Between Aluminum Alloy and Galvanized Steel by CMT, Journal of Materials Engineering and Performance, 25 (2016) 5,1839-1847, doi:10.1007/ s11665-016-2035-2 